\title{
THE INFLUENCE OF PROFESSIONAL QUALIFICATION ON CUSTOMER PERCEPTIONS OF ACCOUNTING SERVICES QUALITY AND RETENTION DECISIONS
}

\author{
Maja ZAMAN GROFF ${ }^{1}$, Sergeja SLAPNIČAR ${ }^{2}$, Neža ŠTUMBERGER ${ }^{3}$ \\ Faculty of Economics, University of Ljubljana, \\ Kardeljeva ploscad 17, 1000 Ljubljana, Slovenia \\ E-mails: ${ }^{1}$ maja.zaman@ef.uni-lj.si (corresponding author); \\ ${ }^{2}$ sergeja.slapnicar@ef.uni-lj.si; ${ }^{3}$ neza.stumberger@gmail.com \\ Received 07 February 2013; accepted 18 October 2013
}

\begin{abstract}
The purpose of this paper is to examine whether professional qualification increases the quality of accounting services as perceived by the customers. We advance the measurement of service quality by industry-specific indicators and establish four dimensions of accounting service quality. We analyse the impact of professional qualification on these dimensions of quality and the impact of these dimensions on customers' retention decisions. The analysis is based on survey data of 237 Slovenian small and micro firms that outsource accounting. We find that professional qualification is positively associated with only one of the perceived service quality dimensions - accounting competences and only assurance, responsiveness and reliability and empathy are positively associated with customers' retention decisions. Limitations of the study are attributed to the measurement of service quality as perceived by the customers. However, this is the only factor of choice that ultimately counts in the competitive market for accounting services.
\end{abstract}

Keywords: accounting services, accounting professional qualification, small and micro firms, service quality, customer perceptions, retention.

JEL Classification: L84, M41, M48.

\section{Introduction}

Due to the public interest dimension of accounting, the accounting profession is strictly regulated, but only where the benefits of safeguarding the public interest from the consequences of market failure offset its costs (O'Regan 2010). It is therefore not surprising that regulation of the accounting profession relates only to public interest companies. Furthermore, it is limited to auditors and does not relate to the provision of accounting services in the narrower sense (i.e. book-keeping and reporting). Currently, the EU regulations include no particular requirements regarding the professional qualifications of accountants. It seems anomalous that preparers of accounts are not subject to the same regulation as auditors yet it may well be that an accountant of an EU public company is not professionally qualified. 
Because of lack of expertise and the related cost, small and micro companies tend to outsource accounting services to professionals that are specialised in the provision of accounting services to small businesses. In a non-regulated setting, providing accounting services to small and micro companies is open to anyone. Furthermore, the trend of regulating financial reporting of small and micro firms is moving away from tighter restrictions: the recently adopted EU Directive 2012/6/EU has introduced financial reporting simplifications for micro companies. Although simplification of financial reporting is desirable from the administrative cost perspective, it may not contribute to higher quality financial information for internal and external users. In these circumstances, service quality delivered by professional accountants is a highly relevant concern.

The purpose of our paper is to analyse whether professional qualification of accountants providing services to small and micro firms is positively associated with the quality of accounting services provided. Service quality is a complex construct, intensively studied in the marketing and quality management literature for the last 30 years (Parasuraman et al. 1985, 1988; Cronin, Taylor 1992; Zeithaml et al. 1996; Rafiq et al. 2012). Existing definitions of service quality are to a large extent applicable to accounting services, but the specifics of this market and the importance of the public interest in particular must be considered and incorporated into this construct. To the best of our knowledge, only few studies have specifically addressed service quality in accounting: Scott and Walt (1995), Aga and Safakli (2007), and Walker et al. (2012). More specifically, the research questions of the study are: 1) to examine which dimensions of accounting service quality are positively associated with professional qualification and 2) to analyse which dimensions of service quality affect customers' retention decisions.

As the setting for our research, Slovenia was chosen as a representative of small Central and East European economies. Due to the relatively short accounting regulation history in these countries (other than in a planned economy) and the lack of strong and established professional organisations, these countries beg the question as to whether regulation of the accounting profession would increase the quality of accounting services.

Our study provides the following contributions to the literature. First, it provides empirical evidence on the effect of professional qualification on accounting service quality and is thus relevant for accounting regulation. Second, it extends prior research by elaborating the construct of accounting services quality. Third, it provides evidence on the dimensions of quality that affect costumers' retention decisions and thus informs accounting firms about factors that underpin long-term relationships with customers. Fourth, it discusses the regulatory implications of the low weight given by customers to professional qualification in the context of the public interest concern. 


\section{Professional qualification, accounting service quality and customers' retention decisions}

In the EU, the vast majority of companies ( 92.2 percent) are micro firms with fewer than ten employees (Annual... 2012). Therefore, small and micro firms have a significant collective impact on national economies.

Although not subject to as much oversight and regulation as financial statements of public companies, financial statements of small and micro companies are important to various groups of users. The question of whether public interest is respected in the nonregulated segment of the accounting services market is therefore of high importance. In the light of the financial crisis, the demand for high quality accounting services is continuously increasing. Although accounting services in the narrow sense (bookkeeping and reporting) are non-regulated, professional organisations organise professional education programmes leading to professional qualifications. Given the scope, sophistication and prices of these programmes they are less suitable for the accountants that provide services to small and micro firms.

Regarding the professional qualification of accountants, abundant literature concentrates on the presentation and comparison of different professional certification training and the relevance of professional certification in accounting education (Strouhal, Zemánek 2008; Boyd et al. 2009; Cory, Huttenhoff 2011; Wheeler, Low and Samkin 2014). However, none of these studies analyses the impact of professional qualification on the quality of services provided.

In the marketing and management quality literature service quality is defined as conformance to customer specifications (Berry et al. 1988: 35; Zeithaml, Bitner 2003). Research suggests that customers perceive service quality as a combination of multiple factors, relevant in a given context. Berry et al. (1988) identify the following five service quality dimensions: reliability, assurance, tangibles, empathy and responsiveness. Different authors suggest diverse types of dimensions for different sectors and there is no clear consensus regarding the dimensions of service quality (Scott, Walt 1995).

Dimensions of service quality in accounting were investigated by Scott and Walt (1995), Armstrong and Davison (1995), Aga and Safakli (2007), and Walker et al. (2012). Scott and Walt (1995) analysed quality dimensions important for the selection of an audit firm. Armstrong and Davison (1995), Aga and Safakli (2007) explored service quality of professional accounting firms operating in Australia and North Cyprus respectively. Walker et al. (2012) investigated management accounting service quality.

In a discussion of the dimensions of accounting services quality, the role of public interest in accounting has to be considered. In line with the Public Interest Framework (recently presented by the International Federation of Accountants), securing the public interest in accounting practice relates primarily to preparation of high quality accounting information, application of high standards of ethical behaviour and sound professional judgment. Ethical behaviour and professional competence are also stressed by the International Ethics Standards Board of Accountants (IESBA) Code of 
Ethics for Professional Accountants (IESBA 2012). The Code requires that accounting professionals comply with five fundamental principles, namely integrity, objectivity, professional competence and due care, confidentiality and professional behaviour. Professional institutions that provide professional qualification programmes appear to broadly promote the notion of public interest and the respect of the Code of Ethics.

Given that professional qualifications are designed to increase the quality of accounting services, our first research question is whether professional qualification of accountants is positively associated with the quality of accounting services as perceived by the customers. We expect that among service quality dimensions professional qualification has the strongest influence on accountants' professional competences, described as the duty to maintain professional knowledge to ensure that clients receive a competent professional service. As professional qualification programmes promote other principles of the Code of Ethics (integrity, objectivity, confidentiality) which to a certain extent resemble the assurance, empathy, responsiveness \& reliability dimensions of service quality, we assume that professional qualification has beneficial effect also on these other dimensions [of service quality]. Therefore, beyond its influence on accountant's professional competences, we expect professional qualification to positively affect assurance, responsiveness \& reliability and empathy.

The association between professional qualification and accounting service quality is also important for accounting professionals when deciding whether it is worth gaining qualifications in terms of competitive advantage. Due to the positive effect of customer retention on the company's profit (Tatikonda 2013) an important question is whether accountants' professional qualification is associated with their customers' retention decisions mediated by the service quality. There is little benefit in holding professional qualifications if customers [who are free to choose] do not distinguish between qualified and unqualified accountants.

In the marketing and quality management literature, service quality is viewed as the central construct that drives customer loyalty (Cronin, Taylor 1992; Zeithaml et al. 1996; Fullerton 2005), which, in turn, is a central determinant of customer retention (Gerpott et al. 2001). The results of prior research related to accounting are somewhat inconclusive: Scott and Walt (1995) report that quality dimensions associated with customers' selection of an audit firm are not significantly associated with actual changes of audit firms.

Beyond increasing competences, a large emphasis in professional qualification is placed on the development of ethical behaviour and accountants' awareness of the public interest. This may not coincide with the interest of the clients. We therefore expect that perceived competences may not be as strongly related to customers' retention decisions as other dimensions of quality because accountants with higher competences may be less subservient to clients as regards reporting of accounting figures. Our second research question is, therefore, which of the quality dimensions are positively associated with customers' retention of their accountant.

Overall, we hypothesise that: i) professional qualification positively affects all dimensions of accounting service quality with the strongest impact being on professional 
competences and ii) customers' retention decisions are positively affected by all dimensions of accounting service quality with assurance, responsiveness \& reliability and empathy having the strongest impact. We present these relationships in the following conceptual mode:

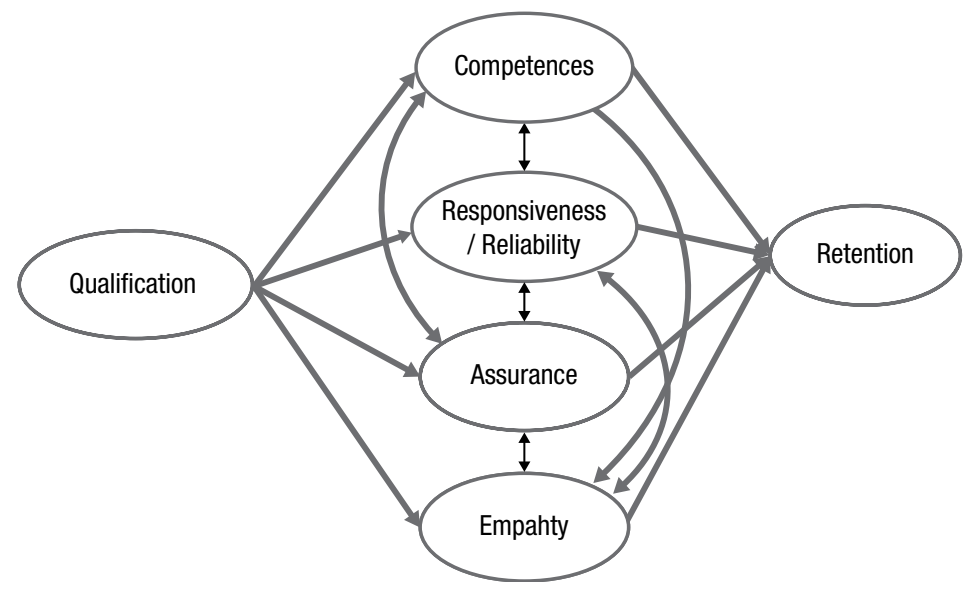

Fig. 1. Conceptual model

\section{Methodology}

\section{Sample}

A random sample of 2,000 small and micro companies was drawn from the Slovenian register of companies Bizi.com. The selection of companies was based on the criteria for small and micro entities as defined in the EU Fourth Directive. The choice of this size of firm is based on the idea that most small and micro firms outsource the accounting function to an external provider, i.e. a professional accounting firm. Hence, the respondents represent the users of accounting services. We sent out e-mail questionnaires to executives in the period August to October 2012. We obtained 382 responses (a 19.1\% response rate). Of these, 280 companies outsource financial reporting to accounting professionals (of these, 43 respondents indicated that they were not aware of whether their accountant has a professional qualification or not) and 102 carry out the financial reporting tasks themselves. We used the responses of the 237 firms that outsource the accounting services and are aware of the qualification of their accountant. The mean education of the respondents is at college degree level. $75 \%$ of the sample firms have fewer than 10 employees.

\section{Construct measurement}

\section{Professional qualification}

The respondents were asked to indicate whether their provider of accounting services has completed one of the professional qualification programmes (QUALIF) organised 
by the Slovenian professional associations. In Slovenia, professional qualification programmes are provided by two professional organisations: The Slovenian Institute of Auditors and the Chamber of Accounting Service Providers. Only candidates with a college or university degree can enrol and the curricula of both programmes focus on accounting, financial reporting, accounting-related regulation, ethics, taxation and corporate, labour and other relevant legislation. The professional qualification of the accountant providing a service to the respondent is measured as a dummy variable.

\section{Accounting service quality}

The instrument to measure service quality in accounting was adapted from the SERVQUAL instrument (Parasuraman et al. 1988). The appropriateness of an unmodified measurement instrument for accounting services is severely limited (Rao, Kelkar et al. 1997) as industry-specific measures of service quality are needed to appropriately measure the construct. The fundamental difference between accounting services and other types of services relates to whom the service provider ultimately serves. Unlike other services, the provision of financial accounting information serves the public interest. From that perspective some quality dimensions may collide; it would, for example, not be appropriate for quality assessment to be dominated by an overly empathic attitude of the accounting firm towards the client.

Similar to many prior studies (Aldhizer et al. 2002; Waldmann, Raghavan 2002; Hong, Goo 2003; Saxby et al. 2004; Aga, Safakli 2007) we follow the original 10-dimensional and the truncated five-dimensional SERVQUAL instrument (Parasuraman et al. 1985; 1988 ) in the development of our instrument. The wording of indicators adapted to the accounting context is based on the Saxby's et al. (2004) study. Given the specific focus of our study, we complemented the scale with additional indicators and omitted one dimension. Additions to the scale were based on in-depth interviews with three accounting experts (practitioners) and our own judgment. It made sense to eliminate the visible dimension of accounting services, i.e. the tangibles. The full list of 29 initial items and their references is available from the authors upon request. The respondents were asked to indicate their personal judgements regarding specific features of accounting services on a 5-point Likert scale.

We explored the dimensionality of researched indicators by performing exploratory factor analysis (principal axis method, rotation varimax). The results are presented in Table 1. A four-factor solution is proposed: 1) competence (COMPET), 2) responsiveness and reliability (RESPREL), 3) assurance (ASSUR) and 4) empathy (EMPAT). The total variance extracted for all constructs is above $60 \%$. Based on the factor analysis and without a loss in terms of substance of the constructs we trimmed the original list of 29 indicators to 21 to increase the discriminant and convergent validity of the constructs in the final structural model. Eight indicators were eliminated in the analysis because of their cross-loadings on different factors or the lack of significant loadings on any factor. 
Table 1. Rotated factor matrix

\begin{tabular}{|c|c|c|c|}
\hline & & RESPREL & COMPET EMPAT ASSUR \\
\hline Q21 & $\begin{array}{l}\text { Employees of the accounting firm } \\
\text { have a professional relationship with } \\
\text { the customers. }\end{array}$ & 0.826 & \\
\hline Q22 & $\begin{array}{l}\text { The behaviour of the accounting } \\
\text { firm employees is in line with their } \\
\text { profession. }\end{array}$ & 0.739 & \\
\hline Q20 & $\begin{array}{l}\text { Employees of the accounting firm } \\
\text { are kind and polite. }\end{array}$ & 0.714 & \\
\hline Q13 & $\begin{array}{l}\text { Employees of the accounting firm are } \\
\text { always willing to help the customer. }\end{array}$ & 0.690 & \\
\hline Q17 & $\begin{array}{l}\text { The accounting firm provides } \\
\text { the services according to agreed } \\
\text { deadlines. }\end{array}$ & 0.686 & \\
\hline Q14 & $\begin{array}{l}\text { Employees of my accounting firm } \\
\text { respond to customers' questions and } \\
\text { requests promptly. }\end{array}$ & 0.629 & \\
\hline Q12 & $\begin{array}{l}\text { Accounting firm's employees provide } \\
\text { the service promptly. }\end{array}$ & 0.592 & \\
\hline Q18 & $\begin{array}{l}\text { The accounting firm provides the } \\
\text { services as was agreed with the } \\
\text { customer. }\end{array}$ & 0.584 & \\
\hline Q15 & $\begin{array}{l}\text { In my accounting firm I am always } \\
\text { informed as to the expected time of } \\
\text { service completion. }\end{array}$ & & \\
\hline Q9 & $\begin{array}{l}\text { Our accountant is acquainted with } \\
\text { the relevant legislation. }\end{array}$ & & 0.771 \\
\hline Q10 & $\begin{array}{l}\text { Our accountant is acquainted with } \\
\text { the accounting standards. }\end{array}$ & & 0.742 \\
\hline Q7 & $\begin{array}{l}\text { Employees of my accounting firm } \\
\text { have the relevant knowledge to } \\
\text { answer my questions. }\end{array}$ & & 0.591 \\
\hline Q11 & $\begin{array}{l}\text { Our accountant regularly engages in } \\
\text { professional training. }\end{array}$ & & 0.587 \\
\hline Q8 & $\begin{array}{l}\text { Our accounting firm possesses } \\
\text { appropriate knowledge specific to } \\
\text { the industry in which our company } \\
\text { operates. }\end{array}$ & & 0.536 \\
\hline Q16 & My accountant is dependable. & & 0.512 \\
\hline Q19 & $\begin{array}{l}\text { Our accountant keeps the records } \\
\text { accurately. }\end{array}$ & & \\
\hline
\end{tabular}


End of Table 1

RESPREL COMPET EMPAT ASSUR

Q23 The accounting firm regularly

informs me of relevant regulatory

changes.

Q27 The accounting firm considers my

0.614

interests in the financial statements

preparation process.

Q28 The accounting firm offers me

0.596

individual attention.

Q29 The accounting firm employees

0.584

always strive to find solutions to my

problems.

Q26 The accounting firm's employees know what my needs are.

Q6 When accounting standards allow greater choice, our accountant always chooses the method that is in the best interests of our company.

Q24 The accounting firm regularly 0.505 keeps track and informs me of the performance of our company.

Q25 The accounting firm provides information in a way that is easily understandable by the customer.

Q5 Our accountant prudently takes into account accounting standards and legislation.

Q1 I feel safe in my transactions with

0.772 my accounting firm's employees.

Q2 I can trust the employees of my accounting firm.

Q4 In the accounting firm privacy is strictly respected.

\subsection{3}

\subsection{7}

I have a formal agreement (contract)

with my accounting firm that clearly

specifies duties and responsibilities

of each party.

\begin{tabular}{llllll}
\hline & & & & & Total \\
\hline$\%$ of Variance & 20.8 & 16.2 & 14.0 & 10.7 & 61.6 \\
\hline
\end{tabular}




\section{Retention decision}

We assess the customer's retention decision (RETENT) by way of two indicators measuring the inclination to keep the same accounting firm for one and for five years. The variable is measured on a scale ranging from 1 to 5, whereby 1 represents improbability and 5 represents certainty that the accountant will be retained [in the future].

\section{Model estimation method}

SmartPLS 2.00 software (Ringle et al. 2005) utilising a partial least squares (PLS) approach to structural equation model (SEM) estimation (Wold 1985; Lohmöller 1989) is used to test the conceptual model summarised in Figure 1. PLS is a components-based structural equation modelling technique that focuses on maximising the explained variance of endogenous target constructs in the model. It is a prediction-oriented variancebased approach. It simultaneously estimates the structural paths and measurement paths in the model using an iterative ordinary least squares (OLS) regression-like procedure. The PLS procedure has been attracting interest among accounting and management researchers in recent years (see Lee et al. 2011; Hair et al. 2012 for an overview); it has an advantage over the variance-covariance based structural equation modelling technique in that it allows the use of both formative and reflective variables in the model (Chin 1998) and is less restrictive regarding the distribution assumptions.

\section{Results}

\section{Measurement model}

As shown in Table 2, the factor loadings for the separate dimensions of quality exceed the 0.7072 threshold, providing evidence of satisfactory individual item reliability. Additionally, we report cross-loadings for all indicators to present the discriminant validity of constructs. To assess the internal consistency of the constructs Table 3 presents Cronbach's $\alpha$ values ranging from 0.826 to 0.941 . Corroborating the Cronbach's $\alpha$ analysis, Dillon-Goldstein's $\rho$ (composite reliability) values are also at around 0.9 for each construct, providing strong evidence of unidimensionality.

Convergent and discriminant validity of the two composite constructs is assessed by the average variance extracted (AVE), which represents the average variance shared between a construct and its indicators. AVE greater than 0.50 indicates satisfactory convergent validity, whereas discriminant validity is assessed by comparisons of AVE to the variance shared between any two constructs. As shown in Table 3, the AVE values for all quality dimensions are greater than the 0.5 cut-off point, indicating an acceptable level of convergent validity. In Table 4, the square roots of the AVE are presented on the diagonal of the correlation matrix, and are all greater than the corresponding correlations. This provides evidence of sufficient discriminant validity of the reflective constructs despite relatively high cross-loadings, showing that each indicator loads higher on its theoretical construct than on any other factors. 
Table 2. Cross-loadings

\begin{tabular}{llllllll}
\hline QUESTION & INDICATOR & QUALIF & COMPET & ASSUR & EMPAT & RESPREL & RETENT \\
\hline Q32 & QUALIF & 1.000 & 0.192 & 0.126 & 0.093 & 0.094 & 0.147 \\
\hline Q9 & COMP1 & 0.178 & $\mathbf{0 . 8 1 8}$ & 0.518 & 0.574 & 0.561 & 0.539 \\
\hline Q10 & COMP2 & 0.157 & $\mathbf{0 . 8 0 4}$ & 0.566 & 0.575 & 0.537 & 0.512 \\
\hline Q7 & COMP3 & 0.086 & $\mathbf{0 . 8 4 1}$ & 0.489 & 0.507 & 0.470 & 0.453 \\
\hline Q11 & COMP4 & 0.114 & $\mathbf{0 . 8 3 4}$ & 0.479 & 0.533 & 0.477 & 0.489 \\
\hline Q8 & COMP5 & 0.237 & $\mathbf{0 . 7 3 9}$ & 0.424 & 0.491 & 0.538 & 0.417 \\
\hline Q1 & ASSUR1 & 0.110 & 0.591 & $\mathbf{0 . 9 2 0}$ & 0.605 & 0.594 & 0.637 \\
\hline Q2 & ASSUR2 & 0.161 & 0.590 & $\mathbf{0 . 9 3 3}$ & 0.608 & 0.607 & 0.645 \\
\hline Q4 & ASSUR3 & 0.041 & 0.395 & $\mathbf{0 . 7 2 5}$ & 0.474 & 0.456 & 0.495 \\
\hline Q26 & EMPATH1 & 0.117 & 0.593 & 0.595 & $\mathbf{0 . 8 4 4}$ & 0.628 & 0.614 \\
\hline Q27 & EMPATH2 & 0.001 & 0.478 & 0.516 & $\mathbf{0 . 8 0 9}$ & 0.571 & 0.552 \\
\hline Q28 & EMPATH3 & 0.110 & 0.569 & 0.522 & $\mathbf{0 . 8 4 7}$ & 0.688 & 0.615 \\
\hline Q29 & EMPATH4 & 0.065 & 0.606 & 0.529 & $\mathbf{0 . 8 6 3}$ & 0.774 & 0.632 \\
\hline Q6 & EMPATH5 & 0.082 & 0.476 & 0.522 & $\mathbf{0 . 7 3 6}$ & 0.528 & 0.575 \\
\hline Q21 & RESPONS1 & 0.097 & 0.407 & 0.457 & 0.569 & $\mathbf{0 . 7 7 8}$ & 0.575 \\
\hline Q22 & RESPONS2 & 0.081 & 0.484 & 0.533 & 0.675 & $\mathbf{0 . 8 8 7}$ & 0.677 \\
\hline Q20 & RESPONS3 & 0.100 & 0.546 & 0.557 & 0.731 & $\mathbf{0 . 8 8 3}$ & 0.701 \\
\hline Q12 & RESPONS4 & 0.103 & 0.601 & 0.591 & 0.678 & $\mathbf{0 . 8 3 7}$ & 0.637 \\
\hline Q13 & RESPONS5 & 0.068 & 0.527 & 0.550 & 0.704 & $\mathbf{0 . 8 7 5}$ & 0.672 \\
\hline Q14 & RESPONS6 & 0.073 & 0.537 & 0.598 & 0.672 & $\mathbf{0 . 8 5 1}$ & 0.675 \\
\hline Q17 & RELIAB1 & 0.047 & 0.620 & 0.530 & 0.613 & $\mathbf{0 . 8 4 9}$ & 0.578 \\
\hline Q18 & RELIAB2 & 0.062 & 0.579 & 0.499 & 0.596 & $\mathbf{0 . 7 6 4}$ & 0.571 \\
\hline Q30 & RETENT1 & 0.112 & 0.541 & 0.621 & 0.700 & 0.768 & $\mathbf{0 . 9 3 1}$ \\
\hline Q31 & RETENT2 & 0.162 & 0.568 & 0.655 & 0.644 & 0.624 & $\mathbf{0 . 9 1 6}$ \\
\hline & & & & & & & \\
\hline
\end{tabular}

Table 3. Quality criteria

\begin{tabular}{lllllll}
\hline & AVE & $\begin{array}{c}\text { Composite } \\
\text { reliability }(\rho)\end{array}$ & $\mathrm{R}^{2}$ & $\begin{array}{c}\text { Cronbachs } \\
\text { alpha }\end{array}$ & Communality & Redundancy \\
\hline QUALIF & & & & & 1.000 & \\
\hline ASSUR & 0.748 & 0.898 & 0.511 & 0.826 & 0.748 & 0.004 \\
\hline COMPET & 0.653 & 0.904 & 0.037 & 0.867 & 0.653 & 0.023 \\
\hline EMPAT & 0.674 & 0.912 & 0.445 & 0.878 & 0.674 & 0.005 \\
\hline RESPREL & 0.709 & 0.951 & 0.413 & 0.941 & 0.709 & 0.005 \\
\hline RETENT & 0.852 & 0.920 & 0.664 & 0.827 & 0.852 & 0.258 \\
\hline
\end{tabular}


Table 4. Correlation matrix

\begin{tabular}{lllllll}
\hline & ASSUR & QUALIF & COMPET & EMPAT & RESPREL & RETENT \\
\hline ASSUR & $\mathbf{0 . 8 6 5}$ & & & & & \\
\hline QUALIF & 0.126 & n.a. & & & & \\
\hline COMPET & $0.616^{* * *}$ & $0.192 *$ & $\mathbf{0 . 8 0 8}$ & & & \\
\hline EMPAT & $0.654 * * *$ & 0.093 & $0.666^{* * *}$ & $\mathbf{0 . 8 2 1}$ & & \\
\hline RESPREL & $0.644^{* * *}$ & 0.094 & $0.642^{* * *}$ & $0.781 * * *$ & $\mathbf{0 . 8 4 2}$ & \\
\hline RETENT & $0.690^{* * *}$ & 0.147 & $0.600^{* * *}$ & $0.729 * * *$ & $0.757^{* * *}$ & $\mathbf{0 . 9 2 3}$ \\
\hline
\end{tabular}

Notes: Diagonal elements (bold) are the square root of the variance shared between the constructs and their indicators (AVE). Off-diagonal elements are the correlations among constructs. For discriminant validity, diagonal elements should be larger than off-diagonal elements. N.a. is non-applicable and relates to the construct measured with one item. ${ }^{* *} \mathrm{p}<0.01,{ }^{* * *} \mathrm{p}<0.001$ (two-tailed test).

\section{Structural model}

Table 5 summarises the structural analysis and Figure 2 provides a diagrammatic representation of the significant structural paths in the proposed model. The predictive validity of the parameter estimates is estimated via a cross-validated redundancy index or so-called Stone-Geisser $\mathrm{Q}^{2}$ test (Geisser 1974; Stone 1974) and $\mathrm{R}^{2}$. As shown in Table 3, the redundancy for all latent variables is satisfactory, with all $\mathrm{Q}^{2}$ values being greater than 0 , providing additional support for the model's predictive relevance.

The estimated path coefficients (see Table 5 and Fig. 2) indicate the strength and the direction of the relationships among the specified variables. The statistical significance of the parameter estimates is assessed using a bootstrap procedure with 1,000 replacements. The analysis shows support for our conjecture that professional qualification has the strongest effect on competences of the accountants. The structural coefficient is positive $(b=0.192, p<0.01)$, while there is no significant association with other dimensions of quality. As argued previously, the association between professional qualification and quality dimensions is more indirect. Competences seem to be indeed an antecedent of other quality dimensions and strongly influence them (COMP $\rightarrow$ ASSUR $b=0.264$, $\mathrm{p}<0.01 ;$ COMP $\rightarrow$ EMPAT $\mathrm{b}=0.284, \mathrm{p}<0.01 ;$ COMP $\rightarrow$ RESPREL $\mathrm{b}=0.647$, $\mathrm{p}<0.01$ ). Not surprisingly, there is also a very high association with assurance, empathy and responsiveness $\&$ reliability.

With respect to the effect of service quality, our study provides support for the association between the standard SERVQUAL dimensions and customers' retention decisions. The structural coefficients between assurance, empathy, responsiveness \& reliability and retention are $0.274,0.230$ and $0.379, \mathrm{p}<0.01$ respectively. We expected the weakest relationship between accountant competences and retention and we find no evidence at all of a direct relationship between the two variables. All in all, it seems that the association between professional qualification and retention by the customer is not direct: it is mediated by perceived competences of the accountant and by their impact on other quality dimensions. 
Table 5. Structural model

\begin{tabular}{|c|c|c|c|c|c|}
\hline & $\begin{array}{l}\text { Original } \\
\text { sample }\end{array}$ & & $\begin{array}{l}\text { Sample } \\
\text { mean }\end{array}$ & $\begin{array}{l}\text { Standard } \\
\text { deviation }\end{array}$ & $\mathrm{T}$ statistics \\
\hline QUALIF -> ASSUR & 0.026 & & 0.024 & 0.051 & 0.508 \\
\hline QUALIF -> COMPET & 0.192 & $* * *$ & 0.194 & 0.060 & 3.176 \\
\hline QUALIF -> EMPAT & -0.018 & & -0.015 & 0.037 & 0.480 \\
\hline QUALIF -> RESPREL & -0.030 & & -0.030 & 0.046 & 0.663 \\
\hline COMPET -> ASSUR & 0.264 & $* * *$ & 0.269 & 0.088 & 3.012 \\
\hline COMPET -> EMPAT & 0.284 & $* * *$ & 0.282 & 0.068 & 4.189 \\
\hline COMPET -> RESPREL & 0.647 & $* * *$ & 0.645 & 0.058 & 11.101 \\
\hline EMPAT -> ASSUR & 0.274 & $* * *$ & 0.280 & 0.114 & 2.406 \\
\hline RESPREL -> EMPAT & 0.602 & $* * *$ & 0.600 & 0.064 & 9.472 \\
\hline RESPREL -> ASSUR & 0.258 & $* * *$ & 0.251 & 0.120 & 2.154 \\
\hline COMPET -> RETENT & 0.035 & & 0.036 & 0.068 & 0.512 \\
\hline ASSUR -> RETENT & 0.274 & $* * *$ & 0.270 & 0.068 & 4.021 \\
\hline EMPAT -> RETENT & 0.230 & $* * *$ & 0.231 & 0.081 & 2.831 \\
\hline RESPREL -> RETENT & 0.379 & $* * *$ & 0.379 & 0.083 & 4.536 \\
\hline
\end{tabular}

Note: $* * \mathrm{p}<0.01, * * * \mathrm{p}<0.001$ (two-tailed test).

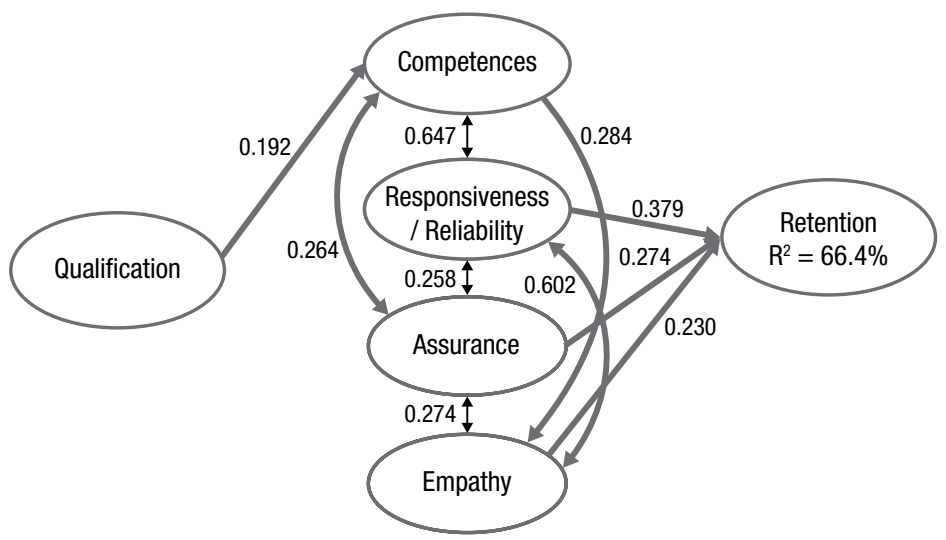

Fig. 2. Estimated path coefficients in the structural model

Note: Only significant paths of the main variables are depicted. Double arrows indicate that associations were also tested in the reverse direction. Results are robust and, for brevity, not reported.

The overall model explains $66.4 \%$ of the variance in customers' retention decisions by the proposed dimensions of quality. Professional qualification only modestly explains the variation in perceived competences (3.7\%). Variance explained in relations between competences and other dimensions exceeds $40 \%$ (see Table 3 ). These findings sug- 
gest that the professional qualification of accountants only weakly explains customer perceptions of accountant competences, but that perceived competences create strong confidence in the accountant that has a beneficial effect on all other dimensions of service quality - assurance, responsiveness \& reliability and empathy. Only these latter dimensions, in turn, affect the customers' retention decisions. Therefore, competences are not of direct importance for a customer in the decision to maintain a certain professional accountant, but are rather an antecedent of other quality dimensions.

\section{Conclusions and discussion}

The purpose of the paper is to raise the question as to whether financial reporting in small and micro firms performed by professional accountants should be (to some extent) regulated in the form of required qualification. We address this question by analysing whether professional qualification positively affects the perceived quality of accounting services provided to small and micro firms, which is expected, in turn, to affect the customer's retention decision. Although the trend in accounting regulation seems to be going in the reverse direction we believe that the issue of regulating the professional preparers of accounts is somewhat different to the lessening of administrative burden of firms. The introduction of minimum required professional qualifications would oblige professional accountancy services providers to comply with certain education, training and ethical standards.

We are not aware of any prior studies investigating the relation between professional qualification, accounting service quality and customers' retention decisions in small and micro firms. One of the contributions of this study is the elaboration of the service quality measurement, appropriate for accounting services. We complemented the existing measurement model with indicators that are industry specific and put an increased emphasis on accountant competences. We identified four dimensions of service quality: competences, assurance, responsiveness \& reliability and empathy. The latter three dimensions coincide with the dimensions of the general service quality model (Parasuraman et al. 1988), in which competences are only a subcomponent of assurance. In our model, on the other hand, competences are a self-standing dimension, which may be particular to the profession under analysis.

We find that professional qualification has a positive impact on customer perceptions of accountants' competences. The explanatory power is, however, low. We further find that competences are positively associated with other aspects of service quality, namely assurance, responsiveness \& reliability and empathy.

Ultimately, our study finds that service quality dimensions impacting on customers' retention decisions are the same as those found in non-accounting studies. In other words, the market will choose those accountants that are perceived as more empathetic, reliable and responsive to individual needs of the customers, those who assure privacy and invoke trust. The competences are of secondary importance. This finding is significant and is in line with the finding of Armstrong and Davison (1995), Aga and Safakli (2007) who also find empathy to be one of the most important dimensions of quality as 
perceived by customers. The finding suggests that the market will not demand formal qualification of accountants, because customers prefer an accountant that is loyal. These characteristics of a personal relationship between a client and an accountant may raise serious concerns regarding an accountant's independence.

The study has some important regulation-related implications. The finding that professional qualification significantly affects professional competences of accountants shows that the market is aware of the benefits of professional qualification. However, the finding that professional competences are not highly valued by the customers in their retention decision suggests that, from the viewpoint of the market, regulation of the accounting profession is not desired. What matters most is the allegiance to the customer. Such an attitude leaves the users of accounting information rather vulnerable and the assurance of public interest remains unsolved. Regulation of the accounting profession is therefore warranted from the viewpoint of the public interest in all those countries in which the market for accounting services is not sufficiently self-regulated in the sense that a professional accountant's affiliation to professional organisations and acquisition of professional competences would be required in order to be accepted by the customers and by the users of accounting information.

The results of the study are hence relevant not only for Slovenia, but also for other Central and East European economies that are questioning whether the regulation of the accounting profession would contribute to increased quality of accounting services. However, to pinpoint and discuss any (potential) country-specific factors, a larger scale, cross-country international research would be necessary.

\section{References}

Aga, M.; Safakli, O. V. 2007. An empirical investigation of service quality and customer satisfaction in professional accounting firms: evidence from North Cyprus, Problems and Perspectives in Management 5(3): 84-98.

Aldhizer, G.; Turner, L.; Shank, M. 2002. Determinants of consulting service quality for accounting and nonaccouting service providers, Journal of Information Systems 16(1): 61-74.

Annual report on small and medium-sized enterprises in the EU, 2011/12. 2012. EU SMEs in 2012: at the crossroads. Brussels: European Commission.

Armstrong, R. W.; Davison, A. 1995. An empirical investigation of the dimensions of service quality in Australian accounting firms, Journal of Customer Service in Marketing \& Management 1(2): 105-122. http://dx.doi.org/10.1300/J127v01n02_10

Berry, L.; Parasuraman, A.; Zeithaml, V. 1988. The service-quality puzzle, Business Horizons 31(5): 35-43. http://dx.doi.org/10.1016/0007-6813(88)90053-5

Boyd, D. T.; Boyd, S. C.; Berry, P. 2009. A primer for accounting certification: complete analysis of the process with listing of sources, American Journal of Business Education 2(7): 83-96.

Chin, W. W. 1998. The partial least squares approach to structural equation modeling, in G. A. Marcoulides (Ed.). Modern methods for business research. Mahwah, NJ: Lawrence Erlbaum Associates, 295-336.

Cory, S. N.; Huttenhoff, T. F. 2011. Perspectives of non-public accountants about accounting education and certifications: an exploratory investigation, Journal of Finance and Accountancy 6: 77-89.

Cronin, J. J.; Taylor, S. A. 1992. Measuring service quality: a re-examination and extension, Journal of Marketing 56(3): 55-68. http://dx.doi.org/10.2307/1252296 
Directive 2012/6/EU of the European Parliament and of the Council amending Council Directive 78/660/EEC on the annual accounts of certain types of companies as regards micro-entities, Official Journal of the European Union, 21 March 2012.

Ewelt-Knauer, C.; Gold, A.; Pott, C. 2013. Mandatory audit firm rotation: a review of stakeholder perspectives and prior research, Accounting in Europe 10(1): 27-41.

http://dx.doi.org/10.1080/17449480.2013.772717

Fullerton, G. 2005. The service quality-loyalty relationship in retail services: does commitment matter?, Journal of Retailing and Consumer Services 12(2): 99-111.

http://dx.doi.org/10.1016/j.jretconser.2004.04.001

Geisser, S. 1974. A predictive approach to the random effect model, Biometrika 61(1): 101-107. http://dx.doi.org/10.1093/biomet/61.1.101

Gerpott, T. J.; Rams, W.; Schindler, A. 2001. Customer retention, loyalty and satisfaction in the German mobile cellular telecommunications market, Telecommunications Policy 25(4): 249-269. http://dx.doi.org/10.1016/S0308-5961(00)00097-5

Hair, J. F.; Sarstedt, M.; Pieper, T. M.; Ringle, C. M. 2012. The use of partial least squares structural equation modeling in strategic management research: a review of past practices and recommendations for future applications, Long Range Planning 45(5-6): 320-340.

http://dx.doi.org/10.1016/j.lrp.2012.09.008

Hong, S.; Goo, Y. J. 2003. An empirical assessment of service quality and customer satisfaction in professional accounting firms, Problems and Perspectives in Management 5(3): 84-98.

IESBA handbook of the code of ethics for professional accountants. 2012. New York: IFAC.

International Federation of Accountants. 2010. IFAC Policy Position Paper \#4: A Public Interest Framework for the Accountancy Profession. New York: IFAC.

Lee, L.; Petter, S.; Fayard, D.; Robinson, S. 2011. On the use of partial least squares path modeling in accounting research, International Journal of Accounting Information Systems 12(4): 305-328. http://dx.doi.org/10.1016/j.accinf.2011.05.002

Lohmöller, J. B. 1989. Latent variable path modeling with partial least squares. Heidelberg: Physica-Verlag. http://dx.doi.org/10.1007/978-3-642-52512-4

O'Regan, P. 2010. Regulation, the public interest and the establishment of an accounting supervisory body, Journal of Management \& Governance 14(4): 297-312.

http://dx.doi.org/10.1007/s10997-009-9102-0

Parasuraman, A.; Zeithaml, V.; Berry, L. 1985. A conceptual model of service quality and its implications for future research, Journal of Marketing 49(3): 41-50. http://dx.doi.org/10.2307/1251430

Parasuraman, A.; Zeithaml, V.; Berry, L. 1988. SERVQUAL: a multiple-item scale for measuring consumer perceptions of service quality, Journal of Retailing 64(1): 12-40.

Rafiq, M.; Lu, X.; Fulford, H. 2012. Measuring Internet retail service quality using E-S-QUAL, Journal of Marketing Management 28(9-10): 1159-1173.

http://dx.doi.org/10.1080/0267257X.2011.621441

Rao, C. P.; Kelkar, M. 1997. Relative impact of performance and importance ratings on measurement of service quality, Journal of Professional Services Marketing 15(2): 69-86.

http://dx.doi.org/10.1300/J090v15n02_06

Ringle, C. M.; Wende, S.; Will, S. 2005. SmartPLS 2.0 (M3) Beta [online], [cited 15 August 2013]. Hamburg. Available from Internet: http://www.smartpls.de.

Saxby, C.; Ehlen, C.; Koski, T. 2004. Service quality in accounting firms: the relationship of service quality to client satisfaction and firm/client conflict, Journal of Business \& Economics Research 2(11): 75-86.

Scott, D. R.; Walt, N. T. 1995. Choice criteria in the selection of international accounting firms, European Journal of Marketing 29(1): 27-39. http://dx.doi.org/10.1108/03090569510075325 
Stone, M. 1974. Cross validity choice and assessment of statistical predictions, Journal of the Royal Statistical Society Series B 36: 111-133.

Strouhal, J.; Zemánek, L. 2008. Certification of the professional accountants in the Czech Republic, Proceedings of World Academy of Science: Engineering \& Technology 43(7): 443-446.

Tatikonda, L. 2013. The hidden cost of customer dissatisfaction, Management Accounting Quarterly 14(3): 34-43.

Waldmann, E.; Raghavan, V. C. S. 2002. Applying marketing science to service quality in accounting, Journal of Applied Management Accounting Research 1(1): 16-30.

Walker, K. B.; Fleischman, G. M.; Johnson, E. N. 2012. Measuring management accounting service quality, Management Accounting Quarterly 13(3): 15-27.

Wold, H. 1985. Partial least squares, in S. Kotz; N. L. Johnson (Eds.). Encyclopedia of Statistical Sciences, vol 6. New York: Wiley, 581-591.

Zeithaml, V.; Berry, L.; Parasuraman, A. 1996. The behavioral consequences of service quality, Journal of Marketing 60(2): 31-46. http://dx.doi.org/10.2307/1251929

Zeithaml, V.; Bitner, M. 2003. Services marketing: integrating customer focus across the firm. 3rd ed. New York: McGraw-Hill.

Maja ZAMAN GROFF. PhD, is an Assistant Professor of accounting and auditing at the Faculty of Economics, University of Ljubljana. She was a member of the Board of the Slovenian Association of Accountants, Treasurers and Auditors and a member of the Council of the Slovenian Institute of Auditors. She has focused her research on auditing and corporate governance related topics and is an audit committee member in a number of Slovenian public companies.

Sergeja SLAPNIČAR. PhD, is an Associate Professor of accounting at the Faculty of Economics, University of Ljubljana. Her research is focused on management control systems and corporate governance. She was a Board member of the Slovenian Agency for Audit Supervision till 2009 and is a supervisory board member or member of audit committees in a number of Slovenian public firms.

Neža ŠTUMBERGER is a practitioner and graduate student of accounting at the Faculty of Economics, University of Ljubljana. She is employed in an accounting firm, providing services to small and micro firms. 